\title{
The Mechanisms of Effective Use of State Sovereign Funds for the Purpose of Investment Development of Regions
}

\author{
Izabella Damdinovna Elyakova $^{1}$, Vladimir Yuryevich Morozov $^{2} \&$ Oksana Borisovna Fedorova $^{3}$ \\ ${ }^{1}$ North-Eastern Federal University, Yakutsk, Russian Federation \\ ${ }^{2}$ The Department of Economics and Management, Russian State University of Tourism and Service, Moscow, \\ Russian Federation \\ ${ }^{3}$ Institute of Geology and Oil and Gas Production Tyumen State Oil and Gas University, Tyumen, Russian \\ Federation \\ Correspondence: Izabella Damdinovna Elyakova, North-Eastern Federal University, Yakutsk, 677000, Russian \\ Federation
}

Received: December 20, 2014 Accepted: December 30, 2014 Online Published: February 25, 2015

doi:10.5539/res.v7n3p43

URL: http://dx.doi.org/10.5539/res.v7n3p43

\begin{abstract}
The relevance of development and improvement of sovereign wealth funds of a state consists in the necessity of defining strategy and development of mechanisms of effective increase and application of money of National Wealth Fund aimed not only at maintenance of capital and achievement of long-term profitability, but also at provision of steady growth of economy of the Russian Federation. The goal of improvement of Wealth Fund of Russia is development of strategy and mechanisms for effective increase and use of its funds. The present study suggests the author's mechanisms for increase and application of National Wealth Fund of Russia with use of experience of leading sovereign investment funds of foreign states and with due consideration of current Russian economic conditions. The realization of mechanism of suggested strategy for effective increase and use of money of National Wealth Fund of the Russian Federation implies gradual transition from today's conservative strategy characterized with the "below average" level of risk to average- and high-risk strategy with expansion of areas of using funds.
\end{abstract}

Keywords: sovereign fund, National Wealth Fund, Russia, effectiveness, priorities, use, increase, factors, risks, investments

\section{Introduction}

Under the modern conditions of development of world economy and international financial relationships the sovereign wealth funds accumulate significant volumes of assets that can be compared in volumes with the largest investment companies, pension and reserve funds of separate countries. By means of it their significance and strategic influence on development of separate branches and national economies on the whole are increased.

The studying of matter about establishment of sovereign funds became of specific relevance taking into account the problem of current consumption of different types of natural resources and partial denial from it to the advantage of saving and provision of stability inside country. In addition, the main part of budget incomes of many states is formed today by means of realization of the very raw commodities - mostly, of oil, gas and minerals. In such a situation the stability of state budget ultimately depends on conjuncture of world costs for these resources.

At the same time, the cost of the present category of goods is being rather volatile and can be forecasted just with small accuracy. In the consequence of this, the fluctuations of costs of the present assets have direct and significant impact on welfare of its citizens. In the period of adverse external conjuncture this causes the necessity in reduction of expenses of federal budget, what often involves negative political and social and economic consequences. And on the contrary - in case of high costs for the present goods the in payments stimulate growth of non-effective state expenses. Under such conditions the non-diminishing volume of expenses preserves from negative consequences for economic and political stability of country, while its reduction in future can lead to quite disadvantageous scenarios. 


\section{Literature Review}

The history of formation and use of sovereign funds keeps positive and negative experience of states, which had decided to save and increase the national capital for good of future generations. Modern researchers have opportunity of studying experience and the best practices on investment of funds by foreign sovereign funds due to availability of information on English web-sites of the funds in the Internet, quarterly analytic research materials of Sovereign Funds Institute and the Center of Sovereign Funds. Such famous philosophers and economists as Turgot (1727-1781), Bentham (1748-1832), Sidgwick (1838-1900), Pareto (1848-1923), Bergson (1859-1941), Pigou (1877-1959), Kaldor (1908-1986), Hicks (1904-1989) Samuelson (1915-2009) and others dedicated their works to the matters of national wealth (Ibraev, 2013).

For the first time ever the theoretical justifications for necessity in creation of such funds for the purpose of achievement of safeguard of assets of nation and future accumulations can be found in the works of Smith (1723-1790). In his work about the nature and reasons for wealth the famous economist gave a detailed account of his ideas about necessity of creation of national fund and also suggested variants for accumulated funds management. The formation of fund of such type, according to Smith, is accounted for withdrawal of part of profit from earnings of major enterprises (Smith, 1935).

The matters of generalization of world and Russian experience of creation of states' sovereign wealth funds are described in works of such Russian scientists and specialists as Danilina (2004), Ibraev (2013), Kazakevich (2007), Kudrin (2006), Levchenko (2012), Petrikova, Zolotareva, Drobyshevsky, Sinelnikova and Kadochkinov (2001). Among the first and main fundamental works dedicated to the matter of creation of Russian sovereign funds we can point out the report of members of Economic Policy Institute named after Gaydar (Zolotareva, Drobyshevsky, Sinelnikova, \& Kadochkinov).

In the sovereign national wealth funds there was accumulation of excess profit that had significantly exceeded the needs of Governing bodies in resources for financing of public expenditures (Kudrin, 2006).

\section{Materials and Methods}

In modern world practice there are three types of governmental reserve (stabilization) funds of financial resources: stabilization, of future generations and budget (Danilina, 2004).

The conditions for creation of sovereign wealth funds as independent influx of currency assets due to auspicious conjuncture of world costs for exported resources and absence of direct target interrelation between sources of formation and fund's liabilities define the specific character of functions performed by the funds. In accordance with this provision Levchenko has pointed out the following functions of sovereign funds:

- Investment;

- Saving;

- Medium-term macroeconomic stabilization;

- Development of national economy;

- State financial assets high-yielding management;

- Sterilization function;

- Pension provision (Levchenko, 2011).

In accordance with designed classification based on differences between the functions performed by funds she has distinguished the following types of funds:

- Stabilization sovereign fund: function-macroeconomic stabilization;

- Reserve sovereign fund (provident fund, wealth fund): being financial reserve, expenditure of which is performed in long-term prospect; the statutory regulation of reserve funds do not provide use of funds in case of occurrence of crisis phenomena. However, for number of funds the use of incomes (part of fund's incomes) for the purpose of current budget financing is provided:

- Sovereign development fund: function — carrying out of investment policy that promotes development of national economy;

- Strategic sovereign fund: function-more profitable state financial assets management. The strategic funds perform active direct and portfolio investments, do not possess one of three above-mentioned functions as main one, include, in particular, sovereign funds created for international reserves management (Levchenko, 2012).

To author's opinion, the classification of Levchenko neatly differentiates the existing majority of sovereign funds 
of developed and developing countries and, what is being more principal, allows following up the evolutionary development of sovereign fund from instrument of stabilization to powerful engine for progressive advance of economy (Levchenko, 2011).

The priorities of using sovereign funds are:

- Investment in financial and real assets on internal and external markets for getting long-term and short-term incomes;

- Creation of financial "safety cushion";

- Financing of current budget's expenditures and settlement of national debt;

- Financial assistance for partner-states.

The main priority area of using funds is the investment of financial assets for mainly long-term period. As the experience of other states having stabilization funds shows, the earnings from financial investments in securities are being the main source of formation of funds (Danilina, 2004).

Except for financial instrument in the form of securities, another issue of big importance is the investment of funds in such infrastructural projects as construction of railways and auto-roads, dwelling-houses and objects of social infrastructure. As far as gradual investments in basic stock within national economy have no significant inflationary effect, they, nevertheless, increase the wealth level of citizens, i.e., there are increase of standard of living, including the quality of obtained medical service and education, increase of employment of population due to creation of new vacancies, renewal of housing funds.

Here we should note that the investment strategy of funds is influenced with two main defining factors:

- Investment risks, i.e., the probability of occurrence of unforeseen financial losses in the situation of uncertainty of conditions for investing;

- Investment goals - advantages obtained by investor as a result of investment of funds (taking a part of profit, the right of participation in management, instituting control over company's activities).

The priority areas of investments are divided by the following criteria:

- Region of investments: European countries, countries of the Middle East and North Africa; countries of South-East Asia, states of BRIC, countries of North America and Latin America, Australia and Oceania;

- Branches of investments: infrastructure (transport, engineering); real estate (commercial, dwelling, industrial, including buildings and land parcels); financial services (insurance, audit, accounting, consulting); telecommunication and informational technologies;

- Type of securities (financial investments): debt obligations of foreign states, foreign government agencies and central banks, international financial organizations and corporations; stocks of companies trading on stock markets;

- Type of real assets (real investments): land parcels, commercial premises, hotel chains, office complexes, equipment.

The creation of safety cushion pursues the aim of adjustment of budget disbalances, maintenance of national currency rate. In this connection the main form of using fund's money is presented with deposits in Central Banks in convertible currencies of foreign states.

The next significant area of using funds is the financing of state's current expenses for:

- Social and pension provision, i.e., the financing of current deficit of Pension Fund for payment of pensions and allowances with account of possible increases, co-financing of contributory pension programs;

- Operative conduction of anti-crisis affairs, in particular, simultaneous increase of authorized capitals of state companies, purchase of securities of strategically important enterprises, direct budget financing of enterprises in the form of loans and subsidies, financial support of enterprises on non-repayable terms at occurrence of natural disasters;

- Currency interventions aimed at conservation and maintenance of national currency rate.

The saving of oil-and-gas incomes gives opportunity of maintaining stable level of public expenditures and, subsequently, provides long-term macroeconomic stability (Kudrin, 2006).

Except for investing and financing of current state's expenditures the money of sovereign fund can be directed to providing financial assistance for partner-states at occurrence of emergency situations, for liquidation of natural 
disasters' consequences, financial and commercial crises. The present direction has major significance for strategic geopolitical development and strengthening of regional and world relations. The main form of provision of assistance is presented with loans.

\section{Discussion and Results}

Taking into account the proposed effective mechanisms of NWF additional fundraising, necessity in the development of priority strategy and its mechanisms of the effective use of NWF of the RF arises.

The proposed strategy of the effective use of the Russian NWF facilities for the purpose of reaching higher return level, retaining financial cushion, and national economy modernization have the following levels of diversification of financial investments:

- The first level - the disposition of financial resources of the Russian NWF in the form of deposits in foreign currency. National Welfare Fund of Russia should invest 20\% of funds of the Russian NWF in deposits in foreign currency (euro, dollar, pounds sterling), and then effect internal financial transactions in roubles;

- The second level - the disposition of financial resources in investments in rating securities of major international corporations (transnational corporations' shares and bonds). Given this, the preference is given to highly liquid bonds as most stable and firm stocks; to our opinion, economically feasible share of investments makes $20 \%$ of the total volume of the Russian NWF;

- The third level — the disposition of financial resources in securities of different countries, at that the preference is given to the European countries, which have the highest credit rating of reliability, investments in real estate the shares we propose are equal to $10 \%$ and $5 \%$ of the total volume of the Russian NWF correspondingly;

- The fourth level - the disposition of financial resources by branches. The enterprises of financial banking sector, energetics, consumer goods area, and telecommunication have a head start in terms of profitability. Direct investments into economy up to $30 \%$ of the total volume of the Russian NWF.

Given this, the existing mechanisms of the Russian NWF funds application provide:

- Financial cushion formation and retaining- $40 \%$;

- Financing of the cumulative part of pensionary funds, Russian pension capital fund deficit funding - $40 \%$;

- Resources of the Russian fund of direct investments- $0 \%$;

- National security retention (loans to states, for example, to the Ukraine-15 bln dollars) $-20 \%$ of the total existing volume of the Russian NWF.

Proposed mechanisms of the effective use of NWF of the RF provide:

- Financial cushion formation and retaining-investment limit-40\%; (including foreign-currency deposits - $20 \%$, investments into highly liquid bonds $-20 \%$ );

- Financing of running budget costs $-40 \%$ (including discharge of foreign debt $-0 \%$, financing of fiscal deficit-10\%, direct investments into domestic economy-30\%);

- Acquisition of long-term and short-term income-15\% (including direct and indirect investments into economies of other countries- $10 \%$, investments in real estate $-5 \%$ );

- National security retention (loans to states) $-5 \%$ of the total existing volume of the Russian NWF.

Proposed priority strategies and mechanisms of the Russian NWF funds effective application in shown in Table 1. 
Table 1. Proposed prospective priority strategies and mechanisms of effective use of NWF funds

\begin{tabular}{|c|c|c|c|c|c|c|c|}
\hline Current priorities: & \multicolumn{2}{|c|}{ 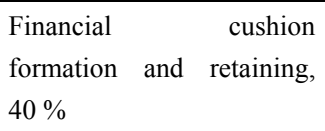 } & \multicolumn{3}{|c|}{$\begin{array}{l}\text { Financing of the cumulative part of } \\
\text { pensionary funds, pension capital fund } \\
\text { deficit funding of Russia, } 40 \%\end{array}$} & $\begin{array}{l}\text { Acquisition of long-term and } \\
\text { short-term income, } 0 \%\end{array}$ & $\begin{array}{l}\text { National safety } \\
\text { retention (loans } \\
\text { to states), } 20 \%\end{array}$ \\
\hline $\begin{array}{l}\text { Current } \\
\text { mechanisms of the } \\
\text { Russian NWF funds } \\
\text { application }\end{array}$ & \multicolumn{2}{|c|}{$\begin{array}{l}\text { Foreign-currency deposits } \\
\text { and investments in highly } \\
\text { liquid bonds }\end{array}$} & \multicolumn{3}{|c|}{$\begin{array}{l}\text { Investments in highly liquid bonds for } \\
\text { acquisition of income }\end{array}$} & $\begin{array}{l}\text { Resources of Russian direct } \\
\text { investment fund }\end{array}$ & Loans \\
\hline $\begin{array}{l}\text { Investment limits, } \\
\text { in total } 100 \% \text {, incl. }\end{array}$ & \multicolumn{2}{|l|}{$40 \%$} & \multicolumn{3}{|l|}{$40 \%$} & $0 \%$ & $20 \%$ \\
\hline Suggested priorities & $\begin{array}{l}\text { Financial } \\
\text { formation an } \\
40 \%\end{array}$ & d retaining, & \multicolumn{3}{|c|}{ Financing of running budget costs, $40 \%$} & $\begin{array}{l}\text { Acquisition of long-term and } \\
\text { short-term income, } 15 \%\end{array}$ & $\begin{array}{l}\text { National safety } \\
\text { retention (loans } \\
\text { to states), } 5 \%\end{array}$ \\
\hline $\begin{array}{l}\text { Proposed } \\
\text { mechanisms of the } \\
\text { Russian NWF funds } \\
\text { application }\end{array}$ & $\begin{array}{l}\text { foreign-curr } \\
\text { ency } \\
\text { deposits }\end{array}$ & $\begin{array}{l}\text { Investments } \\
\text { in highly } \\
\text { liquid } \\
\text { bonds }\end{array}$ & $\begin{array}{l}\text { Discharge } \\
\text { of foreign } \\
\text { debt }\end{array}$ & $\begin{array}{l}\text { Financing } \\
\text { of fiscal } \\
\text { deficit }\end{array}$ & $\begin{array}{l}\text { Direct } \\
\text { investments } \\
\text { in domestic } \\
\text { economy }\end{array}$ & \begin{tabular}{llll} 
Direct & and & & \\
indirect & & \multicolumn{2}{c}{ Investments } \\
investments in & in r real \\
economies of & estate & \\
other countries & &
\end{tabular} & Loans \\
\hline $\begin{array}{l}\text { Investment limits, } \\
\text { in total } 100 \% \text {, incl. }\end{array}$ & $20 \%$ & $20 \%$ & - & $10 \%$ & $30 \%$ & $10 \%$ & $5 \%$ \\
\hline
\end{tabular}

In accordance with the proposed prospective priority strategies and mechanisms of effective use of NWF funds, assigning of funds to financial cushion retaining should be up to $40 \%$ that corresponds to the practices of the best sovereign funds of the world, and the use of approved investment technologies such as investment of $20 \%$ of means in stable income-producing highly liquid debt securities of developed countries and companies with high level of reliability, 20\% - foreign-currency deposits are economically feasible.

The use of gained experience and professional competence of investment managers of the Russian NWF is also relevant. Besides, not only human resources potential can be used, but also carrying out of joint selection and project financing, that will allow increasing the credibility of yield and risk assessment, minimizing predictive risks, threats.

Our offer to direct $30 \%$ of the Russian NWF resources to investment domestic projects financing is proved by the interrelation of investments and economic growth. Samuelson P. described this interrelation in the following way: owing to real investments increase, the increase in GPS takes place, because of GDP growth the increase in real investments occurs.

According to this principle real investments are increase, value growth of production stock and fixed assets, such as equipment, buildings, engines, real estates. As a result of expert comparative analysis of economies of 20 most developed (or rapidly developing) countries for a period of 1961-2005, the credibility and efficiency of above-mentioned "acceleration principle" was proved (owninvest.ru). In studied countries during specified period of time the coefficients of investments and rate of economic growth tend to maximum possible value - one. For developing countries it was necessary to increase real investments by $2.8 \%$ to increase real GPD by $1 \%$. In countries, the economies of which had been rapidly developed during 1991-2006, the index took different values and in a wider range. The main cause was different rate of inflation.

Most critical need for solid direct investments in the economy of the Russian Federation involves large-scale infrastructure projects, such as road construction, public utilities and generation objects replacement, i.e., investments in capital renewals, expansion of production and strategic investments. These investments are characterized by increased risk level.

It's also necessary to diversify the portfolio by means of investments in undervalued shares, foreign states' growing companies' stocks, investments in real estate construction.

The implementation of mechanisms of the proposed strategy by the effective increase and use of the Russian NWF funds is provided by gradual shift from current conservative strategy, characterized by the level of risk below the average, to average-risk, high-risk strategy with extension of funds application ways. Whereas, 
proposed priorities of application are capital investments and investment in the form of securities, their realization is exposed to general and specific investment risks, the level of which is to be assessed quantitatively and proper management methods should be developed. Risks associated with proposed priorities of the effective use of NFW funds is represented in Table 2.

Table 2. Risks associated with proposed priorities of the effective use of NFW funds

\begin{tabular}{|c|c|c|c|c|c|c|c|c|}
\hline $\begin{array}{l}\text { Proposed priorities } \\
\text { with set investment } \\
\text { limit }\end{array}$ & \multicolumn{2}{|c|}{$\begin{array}{l}\text { Financial safety cushion } \\
\text { retaining, } 40 \%\end{array}$} & \multicolumn{3}{|c|}{ Financing of running budget costs, $40 \%$} & \multicolumn{2}{|c|}{$\begin{array}{l}\text { Acquisition of long-term } \\
\text { and short-term income, } \\
15 \%\end{array}$} & $\begin{array}{l}\text { National safety } \\
\text { retention (loans to } \\
\text { states), } 5 \%\end{array}$ \\
\hline $\begin{array}{l}\text { Ways of funds } \\
\text { application }\end{array}$ & $\begin{array}{l}\text { Foreign-c } \\
\text { urrency } \\
\text { deposits }\end{array}$ & $\begin{array}{l}\text { Investment } \\
\text { in highly } \\
\text { liquid } \\
\text { bonds }\end{array}$ & $\begin{array}{l}\text { Discharge } \\
\text { of foreign } \\
\text { debt }\end{array}$ & $\begin{array}{l}\text { Financing } \\
\text { of fiscal } \\
\text { deficit }\end{array}$ & $\begin{array}{l}\text { Direct } \\
\text { investments } \\
\text { in domestic } \\
\text { economy }\end{array}$ & $\begin{array}{l}\text { Direct and } \\
\text { indirect } \\
\text { investments } \\
\text { in economies } \\
\text { of other } \\
\text { countries }\end{array}$ & $\begin{array}{l}\text { Investme } \\
\text { nts in real } \\
\text { estate }\end{array}$ & Loans \\
\hline $\begin{array}{l}\text { Systematic specific } \\
\text { risks }\end{array}$ & $\begin{array}{l}\text { Interest } \\
\text { risk, } \\
\text { currency } \\
\text { risk }\end{array}$ & $\begin{array}{l}\text { Interest } \\
\text { risk, } \\
\text { currency } \\
\text { risk }\end{array}$ & - & $\begin{array}{l}\text { Risk of } \\
\text { inflation, } \\
\text { structure } \\
\text { risk }\end{array}$ & $\begin{array}{l}\text { Risk of } \\
\text { inflation, } \\
\text { conjunctura } \\
1 \text { risk }\end{array}$ & $\begin{array}{l}\text { Interest risk, } \\
\text { selective risk, } \\
\text { temporal risk, } \\
\text { credit risk }\end{array}$ & $\begin{array}{l}\text { Country } \\
\text { risk, } \\
\text { administr } \\
\text { ative risk }\end{array}$ & $\begin{array}{l}\text { Default } \\
\text { political risk }\end{array}$ \\
\hline Risk level & Low & Average & Low & High & High & Average & Low & Average \\
\hline $\begin{array}{l}\text { Investment limits, } \\
\text { in total } 100 \% \text {, incl. }\end{array}$ & $20 \%$ & $20 \%$ & - & $10 \%$ & $30 \%$ & $10 \%$ & $5 \%$ & $5 \%$ \\
\hline $\begin{array}{l}\text { Investments } \\
\text { volume, bln rub. }\end{array}$ & 580 & 580 & - & 290 & 870 & 290 & 145 & 145 \\
\hline Yield, \% & 0.08 & 5 & - & - & - & $5-8$ & 10 & 5 \\
\hline $\begin{array}{l}\text { Yield anticipated } \\
\text { losses, bln. rub. }\end{array}$ & 0.5 & 29 & - & - & - & $14.5-23.2$ & 14.5 & 7.25 \\
\hline $\begin{array}{l}\text { Risk management } \\
\text { method }\end{array}$ & $\begin{array}{l}\text { Risk diver } \\
\text { hedging. } \\
\text { is investec } \\
\text { in time. }\end{array}$ & $\begin{array}{l}\text { ification, risk } \\
\text { te main thing } \\
\text { means return }\end{array}$ & $\begin{array}{l}\text { Risk limitatio } \\
\text { inflation in } \\
\text { compensated } \\
\text { income. }\end{array}$ & $\begin{array}{l}\text {, risk hedgin } \\
\text { he current } \\
\text { with future }\end{array}$ & $\begin{array}{l}\text { High risk of } \\
\text { ears will be } \\
\text { budget fixed }\end{array}$ & $\begin{array}{l}\text { Risk hedging, } \mathrm{r} \\
\text { asset-backed } \\
\text { Possible yi } \\
\text { regarding these }\end{array}$ & $\begin{array}{l}\text { isk sharing, } \\
\text { risks. } \\
\text { ld } \begin{array}{l}\text { loss } \\
\text { trends }\end{array}\end{array}$ & $\begin{array}{l}\text { Limitation. risk } \\
\text { hedging, } \\
\text { co-financing with } \\
\text { states (OECD, EU. } \\
\text { CU, EurAsEC, } \\
\text { APEC, BRIC) }\end{array}$ \\
\hline
\end{tabular}

When assessing possible risks as unfavourable results, the assessment of its type, level, and risk probability is carried out (probability of yield decrease, probability of investment part loss, inflation, etc.).

As we can see in Table 3 priorities of application of funds directed to formation and retention of financial cushion are least risky, besides, the risk of investment in foreign-currency deposits is low and least profitable, the volume of probable losses is $0.5 \mathrm{bln}$. rub. The investments into highly liquid bond are exposed to interest risk, currency risk average level, probable losses are 29 bln. rub.

The priority of running costs financing is related to high degree of inflation risk realization, structural and conjunctural risks, but in the absence of yield probable losses cannot be expressed in money equivalent, because financing of fundamental infrastructure projects is aimed not at receipt of profit from investments, but social effect expressed in improvement of the quality of life, improvement of comfort living in cities, qualitative improvement public and traffic networks.

Direct and indirect investments in the economies of other countries, investments in real estate for the purpose of acquisition of long-term and short-term income are exposed to interest risk, selective risk, temporal risk, and credit risk. Average risk implies probable volume of profitability loss in the amount of 14.5-23.2 bln. rub.

National security retention owing to credit financing of partner states is characterized by the average level of political risk and default risk that is expressed in the earning capacity loss in the amount of $7.25 \mathrm{bln}$. rub. 
Proposed methods of risk minimization:

- Insurance against operating risks via insurance companies or other third parties;

- Assignment of a risk-is a way to avoid transaction risk;

- Cross hedging is used in transactions with countries' companies, the currency of which is bound or correlates well to key currencies, key currencies' rate changes are hedged, which is related to country's currency under consideration.

Risk assessment and application of risk management method will contribute to profitability loss minimization and investments reliability improvement.

\section{Conclusion}

Thus, the effective mechanisms of priority strategy implementation for the Russian NWF income increase are proposed:

- For the Russian NWF income increase by means of entities' capital raising (borrowing costs);

- For the Russian NWF income increase by means of entities' capital raising (additional income);

- For the Russian NWF income increase by means of physical entities' capital raising (borrowing costs).

The proposed strategy and mechanisms of effective use of the Russian NWF resources for the purpose of reaching higher return level, retaining financial cushion and national economy modernization provide the following shared distribution between four priorities:

- Financial cushion formation and retention-investment limit— 40\%; (including foreign-currency deposits-20\%, investments in highly liquid bonds $-20 \%$ );

- Financing of running budget costs $-40 \%$ (including discharge of foreign debt $-0 \%$, financing of fiscal deficit-10\%, direct investments in domestic economy-30\%);

- Acquisition of long-term and short-term income-15\% (including direct and indirect investments in economies of other countries- $10 \%$, real estate investments- $5 \%$ );

- National security retention (loans to states) $-5 \%$ of the total existing volume of the Russian NWF.

Due to implementation of proposed mechanisms of National Wealth Fund use the fund gain will be equal to 84 bln. rub. per year.

\section{References}

Danilina, M. V. (2004). About Russian federal budget stabilization fund formation and management. Scholarly works: The Institute of Economic Forecasting of the Russian Academy of Sciences, 2, 93-111.

Ibraev, R. H. (2013). The role of sovereign funds on modern global capital market. Rossiysky Vneshneekonomichesky Vestnik, 9, 94-98.

Kazakevich, P. A. (2007). Stabilization funds as a special category of stock market participants. Finansy I Kredit, 29.

Kudrin, A. L. (2006). Russian budget petroleum balance formation mechanisms. Voprosy Ekonomiki, 8, 4-16.

Kudrin, A. L. (2006). Stabilization fund: foreign and Russian experience. Voprosy Economiki, 2, 28-45.

Levchenko, A. V. (2011). Sovereign funds as an instrument of state monetary policy. Finansy, 12, 71-72.

Levchenko, A. V. (2012). Investment strategy of Russian sovereign funds and national development. Finansovaya Analitika: Problemy I Resheniya, 3, 38-45.

Petrikova, E. M. (2012). Sovereign funds of national welfare as a tool for financial market stabilization. Finansy I Kredit, 10, 39-49.

Pososhkov, I. T. (1951). Book about poverty and wealth. Moscow: Academic press of Sciences of the USSR.

Samuelson, P. A. (1995). Economics: Class Book (p. 384). Sebastopol: Akhtiar.

Smith, A. (1935). An Inquiry into the Nature and Causes of the Wealth of Nations. Leningrad, Moscow.

Smith, A. (1935). An Inquiry into the Nature and Causes of the Wealth of Nations. Retrieved from http://usib.ru/files/USIB/download/adam_smit_issled_o_priode.pdf

Sukharev, A. N. (2009). Reserve funds and National Wealth Fund: Financial construction and functioning results. Finansy I Kredit, 40, 50-59. 
Zolotareva, A. B., Drobyshevasky, S. M., Sinelnikov, S. G., \& Kadochnikov P. A. (2001). The prospects of stabilization fund formation in the RF. Institute for the Economy in Transition, 27, 76.

\section{Copyrights}

Copyright for this article is retained by the author(s), with first publication rights granted to the journal. This is an open-access article distributed under the terms and conditions of the Creative Commons Attribution license (http://creativecommons.org/licenses/by/3.0/). 